\title{
SIMULTANEOUS COMPLIANCE OF TOC AND TURBIDITY RELATED TO PATHOGEN BREAKTHROUGH AND THMS CONTROL BY ENHANCED COAGULATION
}

\author{
L. RIZZO \\ V. BELGIORNO* \\ R. CASALE
}

Received:10/01/05

Accepted:30/03/05

\author{
Department of Civil Engineering \\ University of Salerno \\ 84084 Fisciano (SA), Italy
}

*to whom all correspondence should be addressed:
Tel: +39 08996 4089; Fax: +39 089964100
e-mail: v.belgiorno@unisa.it

\begin{abstract}
Since discovery of harmful disinfection by products (DBPs) like trihalomethanes (THMs) and haloacetic acids (HAAs) in chlorinated waters the removal of organic DBPs precursors gained priority in drinking water treatment. Historically, coagulation process was arranged to remove turbidity, typically related to pathogens occurrence, but nowadays it is usually optimized/enhanced for total organic carbon (TOC) reduction.

This work dealt with the removal of TOC and turbidity by means of enhanced coagulation process using $\mathrm{Al}_{2}\left(\mathrm{SO}_{4}\right)_{3} \cdot 18 \mathrm{H}_{2} \mathrm{O}$ and $\mathrm{FeCl}_{3} \cdot 6 \mathrm{H}_{2} \mathrm{O}$ as coagulants for jar test without $\mathrm{pH}$ adjustment according to USEPA procedure. $15 \%$ of TOC removal required by USEPA D/DBPs rule (1998) was achieved using $30-50 \mathrm{mg} \mathrm{l}^{-1}$ of both coagulants. On the other hand, for compliance with more stringent MCL for total THMs in Italy $\left(30 \mu \mathrm{g} \mathrm{I}^{-1}\right)$ higher TOC removal (>30\%) which needed of higher coagulants doses $\left(80 \mathrm{mg} \mathrm{l}^{-1}\right)$, was obviously required. Those high coagulant doses were also to be used for the compliance with the turbidity standard (<1NTU).
\end{abstract}

KEYWORDS: enhanced coagulation, pathogens control, TOC and turbidity removal, TTHMFP

\section{INTRODUCTION}

The coagulation process has been primarily used in drinking water treatment to remove turbidity (Eikebrokk, 1999; Volk et al., 2000). Since the discovery of disinfection by products (DBPs) like trihalomethanes (THMs) and haloacetic acids (HAAs) in chlorinated waters (Rook, 1974; Bellar et al., 1974) which are known harmful for human health, the removal of natural organic matter (NOM) has gained growing attention. NOM fraction which is responsible for DBPs formation, is a mixture of humic and fulvic acids; typically characterised by total organic carbon (TOC), dissolved organic carbon (DOC) and UV adsorbance at $254 \mathrm{~nm}$. Edzwald et al. (1985) developed the use of specific ultraviolet absorbance (SUVA; the absorbance at $254 \mathrm{~nm}$ per unit of DOC in $\mathrm{mg} \mathrm{l}^{-1}$ ) as an operational indicator of the composition of organics. SUVA provides a quantitative measure of the aromatic content (aromatic sites substituted with oxygen-and nitrogencontaining functional groups, i.e., phenolics and aromatic amines) of the organic carbon.

Although DBPs formation shifted attention on NOM control, turbidity is an important parameter with reference to microbial risk management in drinking water treatment because of turbidity spikes are considered potential for breakthrough of pathogens. The 
role of turbidity as indicator of pathogen's presence is connected to the electrostatic proprieties of the surface of some microrganisms (Drozd and Schwartzbrod, 1996; Brush et al., 1998; Butkus et al., 2003) and to possibility that they can be removed by coagulants according to same mechanisms by which turbidity is removed during coagulation process (Bustamante et al., 2001). This explains positive correlations $\left(r^{2}=0.93\right)$ between high raw water turbidity ( $>2$ NTU) and the presence of Mycobacterium avium (Falkinham et al., 2001), environmental opportunistic human and animal pathogens (Inderlied et al., 1993).

The efficiency of coagulation depends on several parameters some of which closely connected to variation of weather conditions. The rainstorm events can rapidly change the raw water characteristics leading to elevated levels of turbidity, NOM and sometime microbial load (Kistemann et al., 2002). These changes can result in increasing of coagulant demand hindering the capacity of conventional water treatment (coagulation, sedimentation and filtration). In the recent years some studies were focused on this specific problem suggesting different way to improve coagulation efficiency during rainfall events such as increasing alkalinity to reduce turbidity (Tseng et al., 2000), using ion exchange for NOM control (Fearing et al., 2004), describing a turbidity-based index to identify rainy periods and event that adversely effect the treatment process (Hurst et al., 2004).

For a raw water with high turbidity (10-20 NTU) and relatively high TOC (5-6 mg l-1) with a $\mathrm{pH}$ range of 7.2-8.5, and alkalinity between 46 and $50 \mathrm{mg} \mathrm{CaCO}_{3} \mathrm{I}^{-1}$, the simultaneous removal of TOC and turbidity was demonstrated by means of TOC and turbidity removal domains overlapping in alum coagulation diagram (Amirtharajah's diagram) (Seung-Hyun et al., 2001). If turbidity of water is not excessive the coagulant demand is considered to be dependent on the NOM content (Edzwald and Van Benschoten, 1990; Gregor et al., 1997; Ratnaweera et al., 1999). For hard waters with high alkalinity and pH levels, it is often a matter of discussion from economic and practical perspectives whether to use inorganic acids or coagulant overdosing in order to depress coagulation $\mathrm{pH}$ to optimum levels with respect to NOM removal. Low temperature affects the organic matter removal negatively resulting in increasing residual coagulant concentration in finished water (Exall and Vanloon, 2000).

The Long Term 1 Enhanced Surface Water Treatment Rule (LT1ESWTR) of USEPA (2002) set very stringent limit on effluent turbidity in conventional and direct filtration plants. According to that regulation, turbidity values of $95 \%$ of samples taken each month must be less than or equal to 0.3 NTU and never $>1$ NTU to improve control of microbial pathogens, including specifically the protozoan Cryptosporidium. On the other hand, to protect drinking water consumer from DBPs risk USEPA (1998) promulgated Stage 1 of Disinfectants and Disinfection By-Products (D/DBP) Rule establishing both maximum contaminant levels (MCLs) for four DBPs categories (TTHM, HAAs, bromate and chlorite), in particular $80 \mu \mathrm{g} \mathrm{I}^{-1}$ for TTHMs, and TOC removal requirements for water systems that use conventional filtration treatment. If water treatment plants can not met criteria set in D/DBP Rule, they are allowed to establish alternative TOC removal requirements implementing jar test procedure according to a guidance manual for enhanced coagulation and precipitative softening (USEPA, 1999).

According to the drinking water quality rule of Italy (Official journal of Italy, 1988), any explicit limit for DBPs (except a not better specified limit for organic halogenated compounds) was set up to December 25, 2003. However, recent established legislation (Official journal of Italy, 2001) set very stringent limits for three species of DBPs (TTHMs, chlorite and bromate), in particular for TTHMs $\left(30 \mu \mathrm{g} \mathrm{I}^{-1}\right)$. But no TOC removal was established while 1 NTU turbidity level has to be met.

This work gives the results of NOM (in term of TOC, DOC and $U_{254}$ ) and turbidity removal by means of enhanced coagulation with the aim of simultaneous control of THMs formation and pathogen breakthrough. Experiments were performed on surface water 
samples taken from an artificial basin in southern Italy. Two coagulants $\left(\mathrm{Al}_{2}\left(\mathrm{SO}_{4}\right)_{3} \cdot 18 \cdot \mathrm{H}_{2} \mathrm{O}\right.$ and $\mathrm{FeCl}_{3} \cdot 6 \mathrm{H}_{2} \mathrm{O}$ ) were used for jar test without $\mathrm{pH}$ adjustment according to USEPA procedure for enhanced coagulation.

\section{MATERIALS AND METHODS}

\subsection{Sampling and conservation}

Raw water samples were taken from artificial basin located in province of Salerno (Southern Italy). The basin was constructed to compensate water deficit in tourist season in the region where usually groundwater is consumed. Eleven water samples (S1,.. S11) were collected between February 2002 and March 2003 representing different water conditions and water characteristics, in particular TOC and turbidity parameters.

The raw water samples were collected in $10 \mathrm{~L}$ containers and delivered in to the laboratory in $1 \mathrm{~h}$ to be stored at $4{ }^{\circ} \mathrm{C}$.

\subsection{Jar test procedure}

All samples were brought to room temperature prior to jar testing. Coagulation and flocculation experiments were carried out using ISCO jar test apparatus in 1 I beakers. Following the addition of the coagulants, the samples were subjected to rapid mixing for 1 $\mathrm{min}$ at $100 \mathrm{rpm}$, than flocculation for $30 \mathrm{~min}$ at $30 \mathrm{rpm}$ and last settling for $60 \mathrm{~min}$. Alum $\left(\mathrm{Al}_{2}\left(\mathrm{SO}_{4}\right)_{3} \cdot 18 \mathrm{H}_{2} \mathrm{O}\right)$ and ferric chloride $\left(\mathrm{FeCl}_{3} \cdot 6 \mathrm{H}_{2} \mathrm{O}\right)$ were used as coagulant up to reaching a final coagulant dose of $80 \mathrm{mg} \mathrm{l}^{-1}$ yielding around $7.0 \mathrm{pH}$ which was referred target value by USEPA(1999). The coagulants were added at $10 \mathrm{mg} \mathrm{l}^{-1}$ increases calculated in terms of equivalent to $\mathrm{Al}_{2}\left(\mathrm{SO}_{4}\right)_{3} \cdot 14 \mathrm{H}_{2} \mathrm{O}$ according to USEPA procedure for enhanced coagulation (USEPA, 1999).

To evaluate the coagulation efficiency, raw and treated samples were analyzed without $\mathrm{pH}$ adjustment for $\mathrm{pH}$, turbidity, TOC, DOC, UV ${ }_{254}, \mathrm{SUVA}_{254}$, alkalinity parameters. Bromide was also measured on raw water samples. Iron and aluminium were monitored in raw and coagulated samples.

\subsection{Analytical measurements}

Raw and coagulated samples were filtered through $0.45 \mu \mathrm{m}$ pre-rinsed GMF filter $(25 \mathrm{~mm}$ GD/X, Whatman Inc, USA) for DOC and $U_{254}$ adsorbance measurements. TOC and DOC were measured by SHIMADZU analyser (model 5000A). UV-Vis spectrophotometer was used to measure $\mathrm{UV}_{254}$ absorbance (PerkinElmer, model Lambda12, USA). Turbidity was measured using Hach turbidimeter (model 9024, USA) and $\mathrm{pH}$ was monitored by Hach portable meter (Model 2100N). Iron (AAS, Varian, spectraAA 10 Plus, USA) and aluminium (Metrohm polarograph, 757VA, USA) were also measured.

\section{RESULTS AND DISCUSSION}

\subsection{General}

The raw water characteristics of each sample are given in Table 1. Bromide was below detection limits $\left(<10 \mu \mathrm{gl}^{-1}\right)$. The raw water samples were characterized by relatively high alkalinity $\left(190.3 \pm 2.79 \mathrm{mg} \mathrm{CaCO}_{3} \mathrm{I}^{-1}\right)$ and low TOC $\left(2.81 \pm 0.19 \mathrm{mg} \mathrm{l}^{-1}\right)$ and DOC $(2.74 \pm$ $\left.0.18 \mathrm{mg} \mathrm{l}^{-1}\right)$. A $3.88 \pm 0.28 \mathrm{I} \mathrm{mg} \cdot \mathrm{m}^{-1}$ mean value was obtained for of SUVA indicating that the composition of NOM consisted of the mixture or mostly of aquatic humics (Edzwald et al., 1985) which means the coagulation can be effective in NOM removal (Randtke, 1999). Relatively high turbidity was measured during investigation period (10.66 \pm 6.74 NTU) characterized by strong variations from 4.7 to 29.0 NTU.

According to TOC removal criterion set by USEPA (1998), a 15\% of TOC removal is targeted because raw waters were characterized by both a higher alkalinity $(>120 \mathrm{mg}$ $\left.\mathrm{CaCO}_{3} \mathrm{I}^{-1}\right)$ and lower TOC $\left(<4 \mathrm{mg} \mathrm{I}^{-1}\right)$. 
Table 1. Characteristics of the samples taken from Alento constructed basin and coagulant used for jar test

\begin{tabular}{|c|c|c|c|c|c|c|c|c|}
\hline Sample & $\mathrm{pH}$ & $\begin{array}{c}\text { Alkalinity } \\
\left(\mathrm{mg} \mathrm{I}^{-1}\right)\end{array}$ & $\begin{array}{l}\text { Turbidity } \\
\text { (NTU) }\end{array}$ & $\begin{array}{c}\text { TOC } \\
\left(\mathrm{mg} \mathrm{l}^{-1}\right)\end{array}$ & $\begin{array}{c}\text { DOC } \\
\left(\mathrm{mg} \mathrm{l}^{-1}\right)\end{array}$ & $\begin{array}{l}U V_{254} \\
\left(1 \mathrm{~cm}^{-1}\right)\end{array}$ & $\begin{array}{c}\text { SUVA } \\
\left(\mathrm{I} \mathrm{mg.}^{-1}\right)\end{array}$ & Coagulant \\
\hline S1 & 7.4 & 183.4 & 29.0 & 3.32 & 3.22 & 0.123 & 3.82 & Alum \\
\hline S2 & 7.4 & 190.9 & 15.0 & 2.80 & 2.79 & 0.108 & 3.87 & Alum \\
\hline S3 & 7.4 & 190.9 & 10.0 & 2.80 & 2.72 & 0.099 & 3.64 & Alum \\
\hline S4 & 7.4 & 188.5 & 9.0 & 2.76 & 2.60 & 0.100 & 3.85 & $\mathrm{FeCl}_{3}$ \\
\hline S5 & 7.5 & 189.4 & 8.0 & 2.71 & 2.66 & 0.102 & 3.83 & Alum \\
\hline S6 & 7.4 & 193.5 & 8.0 & 2.80 & 2.77 & 0.128 & 4.62 & $\mathrm{FeCl}_{3}$ \\
\hline S7 & 7.3 & 192.2 & 8.0 & 2.90 & 2.86 & 0.112 & 3.92 & Alum \\
\hline S8 & 7.5 & 189.7 & 12.4 & 2.84 & 2.75 & 0.098 & 3.56 & $\mathrm{FeCl}_{3}$ \\
\hline S9 & 7.7 & 191.9 & 8.0 & 2.66 & 2.59 & 0.102 & 3.94 & Alum \\
\hline S10 & 7.7 & 193.2 & 4.7 & 2.61 & 2.56 & 0.102 & 3.98 & Alum \\
\hline S11 & 7.7 & 190.0 & 5.3 & 2.72 & 2.64 & 0.097 & 3.67 & $\mathrm{FeCl}_{3}$ \\
\hline Average & $7.49 \pm 0.14$ & $190.3 \pm 2.79$ & $10.66 \pm 6.74$ & $2.81 \pm 0.19$ & $2.74 \pm 0.18$ & $0.11 \pm 0.01$ & $3.88 \pm 0.28$ & \\
\hline Range & 7.3-7.7 & 183.4-193.5 & $4.7-29.0$ & $2.61-3.32$ & $2.56-3.22$ & $0.1-0.13$ & $3.56-4.62$ & \\
\hline
\end{tabular}

\subsection{The pH}

Although final $\mathrm{pH}$ was dependent on the coagulant type and alkalinity, no significant difference in final $\mathrm{pH}$ values of alum (Figure 1a.) and $\mathrm{FeCl}_{3}$ (Figure 1b.) experiments were observed. Around 7.0 of target pH was reached in the range of $30-50 \mathrm{mg} \mathrm{l}^{-1}$ of equivalent dose for alum and $30-40 \mathrm{mg} \mathrm{I}^{-1}$ of equivalent dose for $\mathrm{FeCl}_{3}$ of which residual $\mathrm{Al}$ and $\mathrm{Fe}$ ion concentrations did not exceed the limit $\left(<0.2 \mathrm{mg}^{-1}\right)$

\subsection{Organic DBPs precursors removal}

The results of the jar test (in terms of TOC, DOC and $U_{254}$ ) showed high NOM removal efficiencies (>30\%) for both coagulants for all samples (Figure2a, b) using $80 \mathrm{mg} \mathrm{l}^{-1}$ as equivalent dose which allowed to remove almost 33 and $36 \%$ of TOC for alum and $\mathrm{FeCl}_{3}$, respectively (Table 2). However, $16 \%$ of TOC removal was obtained at target $\mathrm{pH}$.

Alum proved highest TOC removal for S1 due to its high initial TOC value $\left(3.32 \mathrm{mg} \mathrm{l}^{-1}\right)$ while for other samples the NOM removal were similar due to a narrow range of TOC and SUVA (3.8-3.9 $1 \mathrm{mg} \cdot \mathrm{m}^{-1}$ ) (Figure 2a). $\mathrm{FeCl}_{3}$ yielded the best NOM removal efficiency for

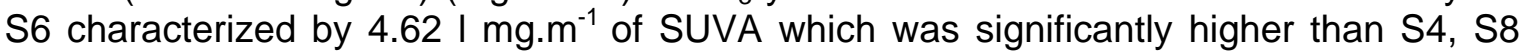
and S11 samples (Figure 2b). The composition of NOM by means of SUVA consists of the mixture or mostly of aquatic humics as hydrophobic character with moderate/high molecular weight (Edzwald et al., 1985) for which coagulation is very effective for NOM removal (Randtke, 1999).

Our previous study on the same raw water showed that TTHM formation potential (TTHMFP) concentrations in raw water varied between 120-200 $\mathrm{g} \mathrm{I}^{-1}$ (Bekbolet et al., 2004) and it could be lowered to $30 \mu \mathrm{g} \mathrm{I}^{-1}$ using 30-40 mg l-1 of alum and $\mathrm{FeCl}_{3}$ for initial $2.7 \mathrm{mg} \mathrm{l}^{-1}$ of TOC and $185 \mathrm{mg} \mathrm{l}^{-1}$ of alkalinity (Rizzo et al., 2004). Hence, the present results given in Table 2 are indicative for compliance with required TOC removal and for lowering TTHMFP. 


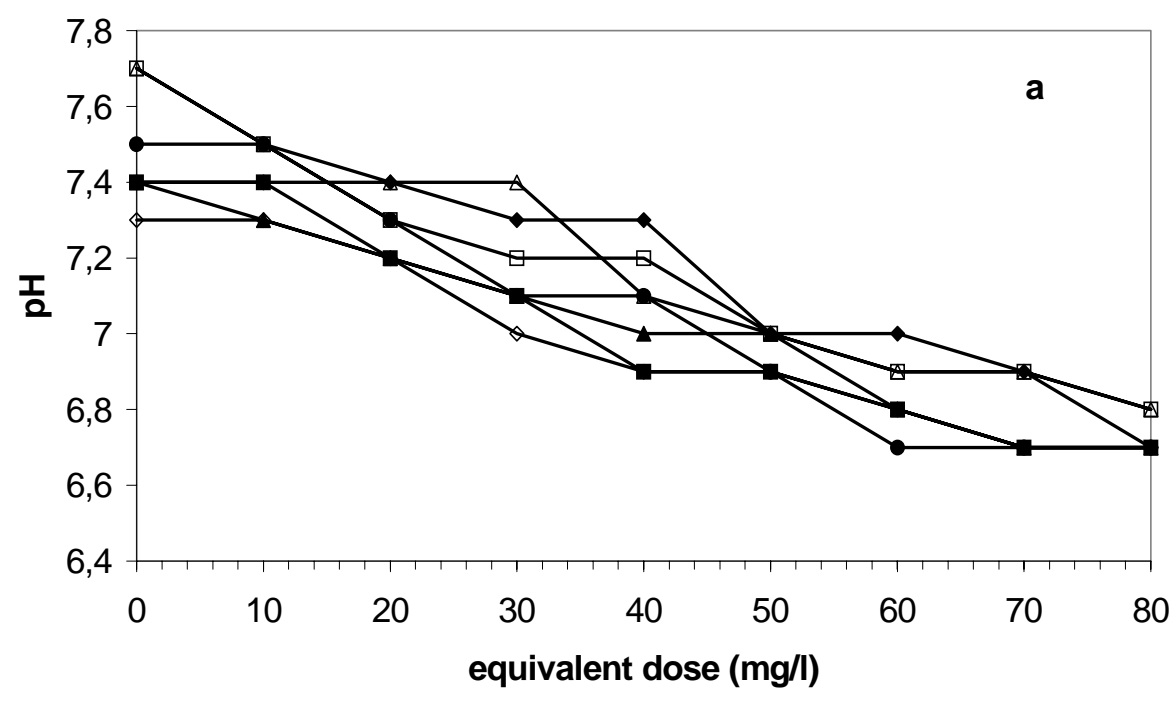

$-\mathrm{S} 1 \rightarrow \mathrm{S} 2 \rightarrow \mathrm{S} 3 \rightarrow \mathrm{S} 5 \rightarrow \mathrm{S} 7+\mathrm{S} 9 \rightarrow \mathrm{S} 10$

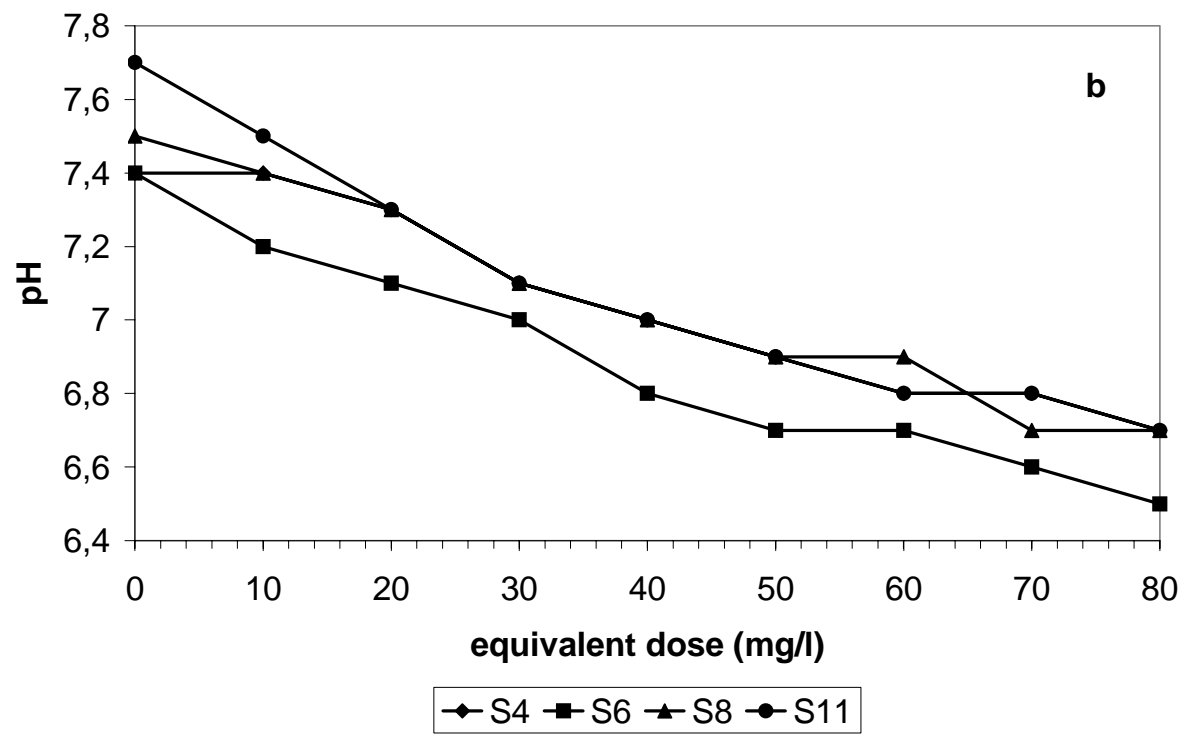

Figure 1. pH behaviour for alum (a) and ferric chloride (b) experiments

\subsection{Simultaneous TOC and turbidity compliance}

Although high NOM removal efficiencies were obtained by enhanced coagulation, coagulation experiments did not provide lower turbidity values than 2.0 NTU for alum and 1.2 NTU for $\mathrm{FeCl}_{3}$ at target $\mathrm{pH}$. However, using $80 \mathrm{mg} \mathrm{l}^{-1}$ of equivalent coagulant doses turbidity could be lowered to lesser than 1 NTU (Table 3).

For controlling of pathogens simultaneously to turbidity removal, the capacity of filtration unit to reduce turbidity up to 0.3 NTU according to standard set in LT1ESWTR (USEPA, 2002) should be controlled very strictly. If filtration unit cannot provide this result, coagulation process should be enhanced for optimal removal of turbidity rather than TOC, increasing coagulant dose above target $\mathrm{pH}$ as well as corresponding residual iron or aluminium salts in the effluent.

In Italy, where higher TOC removal efficiencies are required due to more stringent TTHMs limit, $\mathrm{pH}$ target removal could not provide to reduce TOC which requires the use of higher 
coagulant doses. However, rather than TOC turbidity removal could be limiting factor in the evaluation of coagulation process.
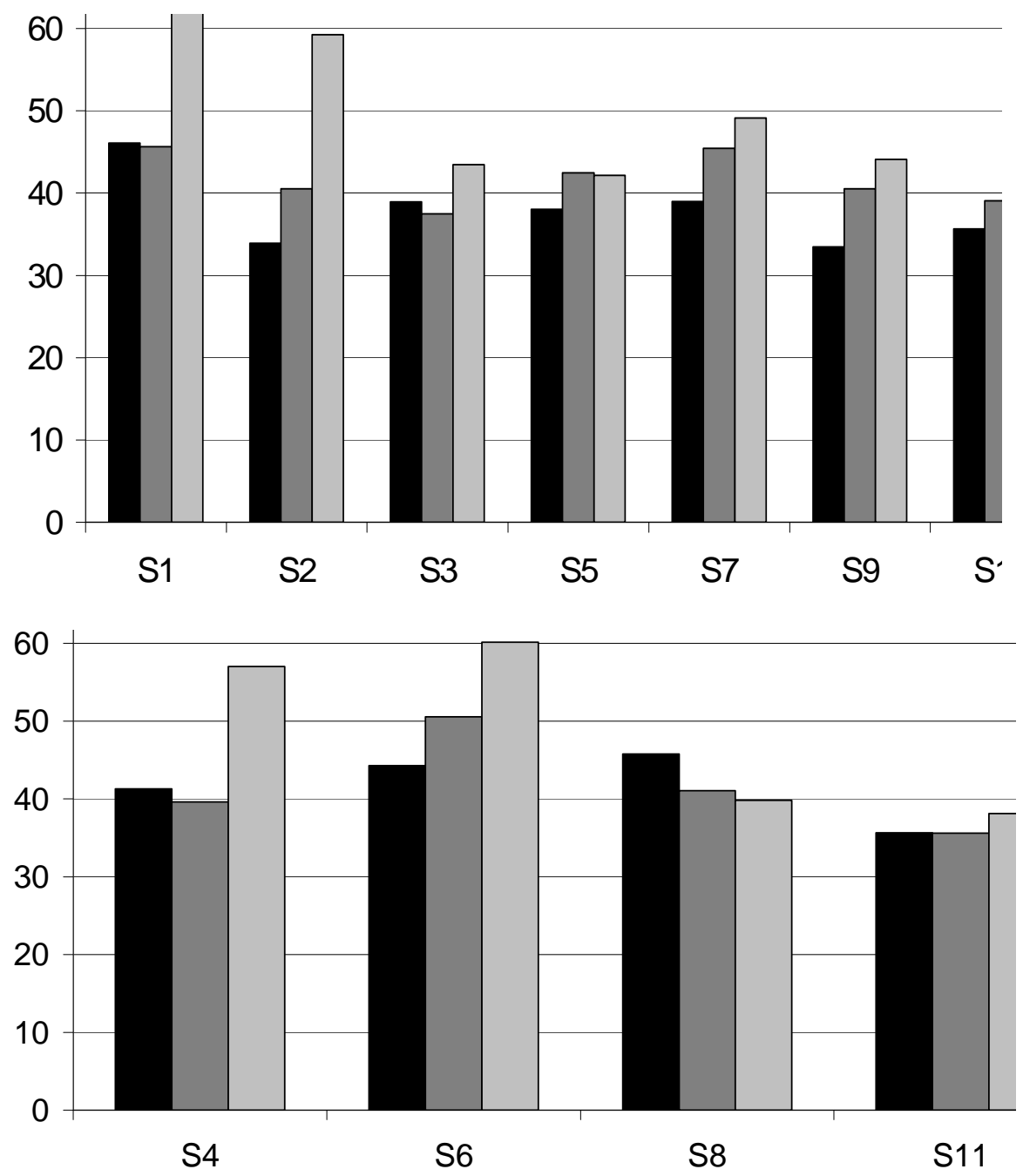

Figure 2. organic THMs precursors removals using alum (a) and ferric chloride (b).

Table 2. TOC removal at both target $\mathrm{pH}$ and maximum coagulant dose.

\begin{tabular}{|c|c|c|c|c|c|}
\hline \multirow{2}{*}{$\begin{array}{l}\text { Coagu } \\
\text { lant }\end{array}$} & \multirow[t]{2}{*}{ Samples } & \multicolumn{2}{|c|}{ target $\mathrm{pH}$ removal } & \multicolumn{2}{|c|}{ Max. dose removal } \\
\hline & & $\begin{array}{c}\text { Dose } \\
\left(\mathrm{mg} \mathrm{l}^{-1}\right)\end{array}$ & TOC removal (\%) & $\begin{array}{c}\text { Dose } \\
\left(\mathrm{mg} \mathrm{l}^{-1}\right)\end{array}$ & $\begin{array}{c}\text { TOC } \\
\text { remova } \\
(\%)\end{array}$ \\
\hline Alum & $\begin{array}{c}\text { S1-S3, S5, S7, S9, } \\
\text { S10 }\end{array}$ & $30-50$ & $16-36$ & 80 & $33-46$ \\
\hline $\mathrm{FeCl}_{3}$ & S4, S6, S8, S11 & $30-40$ & $22-30$ & 80 & $36-46$ \\
\hline
\end{tabular}

Table 3. Turbidity removal at both target $\mathrm{pH}$ and maximum coagulant dose

\begin{tabular}{lccccccc}
\hline Type & \multirow{2}{*}{ Samples } & \multicolumn{3}{c}{ target $\mathrm{pH}$ removal } & \multicolumn{3}{c}{ Max. dose removal } \\
\cline { 3 - 8 } & & $\begin{array}{c}\text { Dose } \\
\left(\mathrm{mg} \mathrm{l}^{-1}\right)\end{array}$ & $\begin{array}{c}\text { NTU } \\
(\%)\end{array}$ & $\begin{array}{c}\text { Final } \\
\text { NTU }\end{array}$ & $\begin{array}{c}\text { Dose } \\
\left(\mathrm{mg} \mathrm{I}^{-1}\right)\end{array}$ & $\begin{array}{c}\text { NTU } \\
(\%)\end{array}$ & $\begin{array}{c}\text { Final } \\
\text { NTU }\end{array}$ \\
\hline Alum & S1-S3, S5, S7, S9, S10 & $30-50$ & $50-83$ & $1.9-6$ & 80 & $77-93$ & $0.8-2$ \\
$\mathrm{FeCl}_{3}$ & S4, S6, S8, S11 & $30-40$ & $37-81$ & $1.2-5$ & 80 & $75-95$ & $0.6-2$ \\
\hline
\end{tabular}




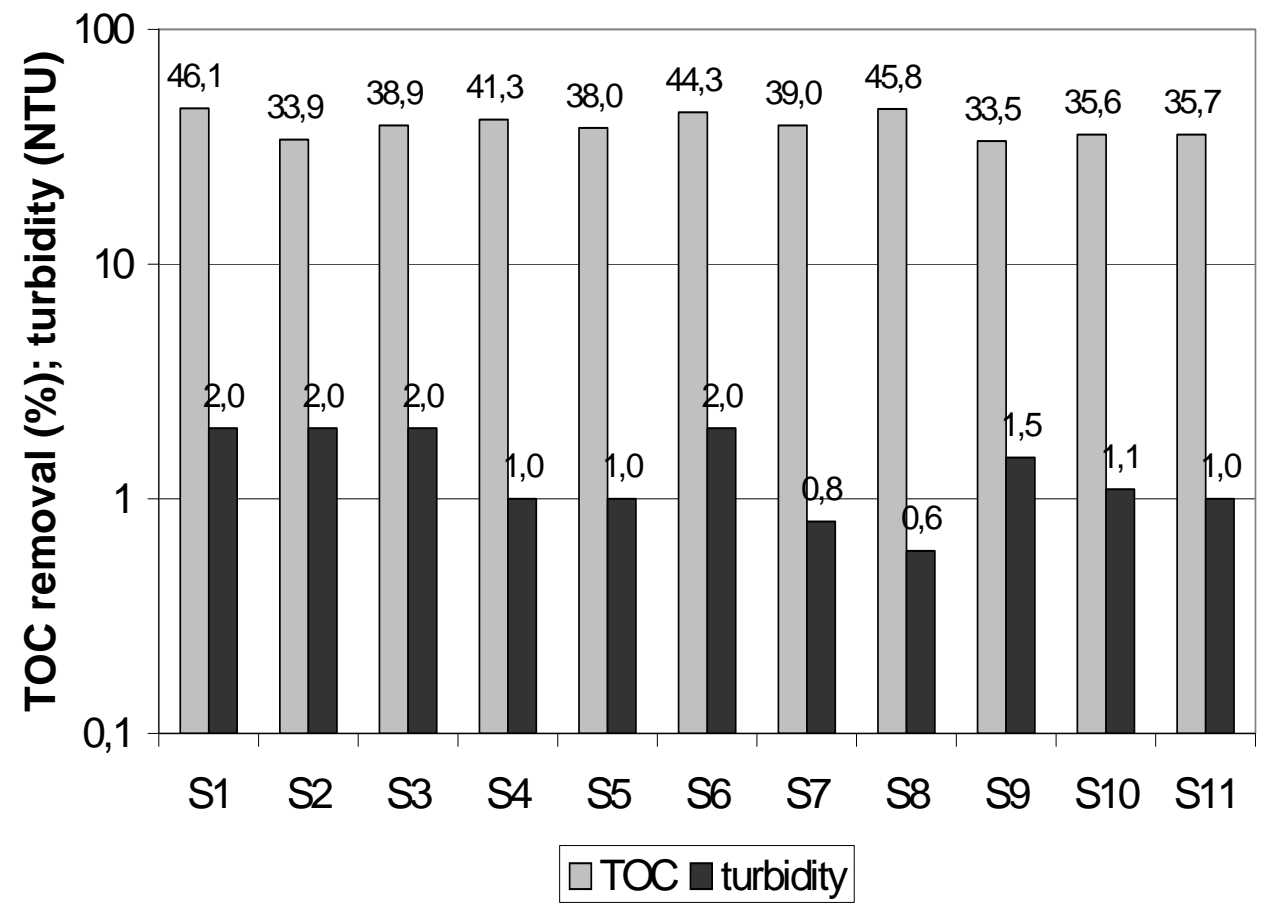

Figure 3. Simultaneous TOC and turbidity removal at $80 \mathrm{mg} / \mathrm{l}$ as equivalent coagulant dose

Figure 3 shows the resulting turbidity and TOC removals obtained using $80 \mathrm{mg} \mathrm{l}^{-1}$ of equivalent coagulant dose for all samples. TOC removals ranged between $33-46 \%$.

Keeping in mind that previous studies established that to obtain effective removal of Giardia and Cryptosporidium the turbidity of filtered water has to be keep in the range of 0.1-0.2 NTU (Logsdon et al., 1985; Al-Ani et al., 1986; Niemiski and Ongerth, 1995) Italian standard for turbidity ( $<1$ NTU) seems to be relative high to control the risk of pathogen breakthrough. A further integrative treatment to coagulation/filtration, e.g., granular activated carbon adsorption or enhanced sand/micro filtration would be proper to decrease the over coagulant doses which could result in high residual iron or aluminium ion in finished water (Srinivasan et al., 1999) as well their toxicity risk (Pagano et al., ; Melluso et al., 2004).

\section{CONCLUSIONS}

Coagulation process can be effective for simultaneous control of organic precursors of THMs formation and pathogen breakthrough. Both the correlation between NOM and THMs formation and the positive evidence found between turbidity and some pathogens force to evaluate the approach of simultaneous compliance for THMs precursors and turbidity removal. The following results were obtained in this study:

The TOC removal was always higher than $16 \%$ at target $\mathrm{pH}$ in compliance with TOC removal requirement (15\%) set by USEPA (1999) enhanced coagulation procedure for raw water with low TOC $(<4.0 \mathrm{mg} / \mathrm{l})$ and high alkalinity $\left(>120 \mathrm{mg} \mathrm{CaCO}_{3} / \mathrm{l}\right)$ by using $30-$ $40 \mathrm{mg} \mathrm{l}^{-1}$ of alum and $\mathrm{FeCl}_{3}$ doses. However, at target $\mathrm{pH}$ turbidity removal was rather limiting parameter than TOC removal for compliance with both Italian turbidity limit $(<1$ NTU) and USEPA limit (2002) for pathogen control. 
For TOC removal requirement according to Italian low limit for TTHM, $80 \mathrm{mg} \mathrm{l}^{-1}$ equivalent dose of alum and $\mathrm{FeCl}_{3}$, yielding 33 and $36 \%$ of TOC removal as well as $<1$ NTU for alum and $\mathrm{FeCl}_{3}$ respectively, were to be used.

On the other hand, to reach turbidity values in the range of 0.1-0.2 NTU for pathogen breakthrough control, integrative treatment such as granular activated carbon adsorption, sand/micro filtration could be necessary to avoid from using overdoses of coagulants.

\section{ACKNOWLEDGEMENTS}

The authors would like to thank Ph.D. S. Meriç for her contribution on this paper. Authors are grateful to MIUR (Italian Ministry for Research, University and Instruction) which funded in part this work and to drinking water utilities for the collaboration in Salerno (ASIS, Pluriacque).

\section{REFERENCES}

Al-Ani M.Y., Hendriks D.W., Logsdon G.S., Hibler C.P. (1986), Removing Giardia Cysts from low turbidity waters by rapid rate filtration. J Am Water Works Assoc., 78 (5), 66-73.

APHA/AWWA/WEF (1998), Standard Methods for the Examination of Water and Wastewater $20^{\text {th }}$ Ed. American Public Health Association/American Water Works Association/Water Environment Federation. Washington D.C., USA.

Bekbolet M., Rizzo L., Belgiorno V., Napoli R.M.A., Meriç S. (2004), Evaluation of TTHMs formation in drinking water: Istanbul (Turkey) and Salerno (Italy) cases. In proceedings of SIDISA 2004, International Symposium of Environmental Engineering, 23-26 June 2004, Taormina, Italy.

Bellar T.A., Lichtenberg J.J., Kroner R.C. (1974), The occurrence of organohalides in chlorinated drinking water. J Am. Water Works Assoc., 66 (12), 703.

Brush C.F., Walter M.F., Anguish L.J., Ghiorse W.C. (1998), Influence of pretratment and experimental conditions on electrophoretic mobility and hydrophobicity of Cryptosporidium parvum oocysts. Appl. Environ. Microbiol., 64 (11), 4439-4445.

Bustamante H.A., Shanker S.R., Pashley R.M. Karaman M.E. (2001), Interaction between Cryptosporidium oocysts and water treatment coagulants. Wat. Res., 35, 3179-3189.

Butkus M.A., Bays J.T., Labare M.P. (2003), Influence of surface characteristics on the stability of Cryptosporidium parvum oocysts. Appl. Environ. Microbiol,. 69 (7), 3819-3825.

Drozd C., Scwartzbrod J. (1996), Hydrophobic and electrostatic cell surface properties of Cryptosporidium prvum. Appl. Environ. Microbiol., 62 (4), 1227-1232.

Edzwald J.K., Becker W.C., Wattier K.L. (1985), Surrogate parameters for monitoring organic matter and THM precursors. J Am Water Works Assoc., 77 (4), 122-132.

Edzwald J.K. and Tobiason J.E. (1999), Enhanced coagulation: US requirements and a broader view. Wat. Sci. Tech., 40 (9), 63-70.

Edzwald J.K. and Van Benschoten J.E. (1990), Aluminium coagulation of natural organic material. In Chemical Water and Wastewater Treatment. Hahn H.H. and Klute R. (eds) Berlin: SpringerVerlag.

Eikebrokk B. (1999), Coagulation-direct filtration of soft, low alkalinity humic waters. Wat. Sci. Tech., 40 (9), 55-62.

Exall K.N. and Vanloon G.W. (2000), Using coagulants to remove organic matter. J Am. Water Works Assoc., November, 93-102.

Falkinham III J.O., Norton C.D., LeChevallier M.W. (2001), Factors influencing numbers of Mycobacterium avium, Mycobacterium intracellulare, and other Mycobacteria in drinking water distribution systems. Appl. Environ. Microbiol,. 67 (3), 1225-1231.

Fearing D.A., Banks J., Guyetand S., Eroles C.M., Jefferson B., Wilson D., Hillis P., Campbell A.T., Parsons S.A. (2004), Combination of ferric and MIEX for the treatment of a humic rich water. Wat. Res., 38, 2551-2558.

Gregor J.E., Nokes C.J., Fenton E. (1997), Optimising natural organic matter removal from low turbidity waters by controlled $\mathrm{pH}$ adjustment of aluminium coagulation. Wat. Res., 31 (12), 2949-2958.

Hurst A.M., Edwards M.J., Chipps M., Jefferson B., Parsons S.A. (2004), The impact of rainstorm events on coagulation and clarifier performance in potable water treatment. Sci. Tot. Environ., 321, 219-230. 
Inderlied C.B., Kemper C.A., Bermudez L.E.M. (1993), The Mycobacterium avium complex. Clin. Microbiol. Rev., 6, 266-310.

Kistemann T., Claben T., Koch C., Dangendorf F., Fischeder R., Gebel J., Vacata V., Exner M. (2002), Microbial load of drinking water reservoir tributaties during extreme rainfall and runoff. Appl. Environ. Microbiol., 68 (5), 2188-2197.

Logsdon G.S., Thurman V.C., Frindt E.S., Stoecker J.G. (1985), Evaluating sedimentation and various filter media for removal of Giardia Cysts. J Am Water Works Assoc., 77 (2), 61-66.

Melluso M., Guida M., Mattei L., Pagano G., Meric S. (2004), Daphnia magna and Selenastrum capricornutum in evaluating the toxicity of alum and polymer used in coagulation-flocculation. Fresenius Envir. Bull.,13 (in press).

Nieminski E.C. and Ongerth J.E. (1995), Removing Giardia and Cryptosporidium by conventional treatment and direct filtration. J Am Water Works Assoc., 87 (9), 96-106.

Official Journal of Italy (1988). D.P.R. $236 / 88$ on drinking water quality, addition to official journal, number 152, June, 30, 1988.

Official Journal of Italy (2001). D.Lgs 31/2001 on drinking water quality, addition to official journal, number 52, March, 3, 2001.

Pagano G., His E., Beiras R., De Biase A., Korkina L.G., laccarino M., Oral R., Quiniou F., Warnau M., Trieff N.M. (1996), Cytogenetic, developmental and biochemical effects of aluminum, iron and their mixture in sea urchins and mussels. Arch. Environ. Contam. Toxicol., 31, 466-474.

Randtke S.J. (1999), Disinfection by-product precursor removal by coagulation and precipitative softening. In Formation and control of disinfection by-products in drinking water. Singer P.C. (ed), AWWA, New York.

Ratnaweera H., Gjessing E., Oug E. (1999), Influence of physical-chemical characteristics of natural organic matter (NOM) on coagulation properties: an analysis of eight Norwegian water sorurces. Wat. Sci. Tech., 40 (4-5), 89-95.

Rizzo L., Belgiorno V., Meriç S. (2004), Organic THMs precursors removal from surface water with low TOC and high alkalinity by enhanced coagulation. In proceedings of $4^{\text {th }}$ IWA World Water Congress and Exhibition, 19-24 September 2004, Marrakech, Morocco.

Rook J.J. (1974), Formation of haloforms during chlorination of natural waters. Water Treat. Exam, 23 (2), 234-243.

Seung-Hyun K., Byung-Hyun M., Hyang-In L. (2001), Effect of pH and dosage on pollutant removal and floc structure during coagulation. Microchem. J., 68, 197-203.

Srinivasan P.T., Viraraghavan T., Subramanian K.S. (1999). Aluminium in drinking water: An overview. Water SA, 25 (1), 47-55.

Tseng T., Segal B.D., Edwards M. (2000), Increasing alkalinity to reduce turbidity. J Am Water Works Assoc., 92 (6), 44-54.

USEPA (1998), National primary drinking water regulations: disinfectants and disinfection byproducts. Final rule Final Rule Fed. Reg., 63/241/69478, Cincinnati.

USEPA (1999), Enhanced Coagulation and Enhanced Precipitative Softening Guidance Manual. EPA 815-R-99-012, Cincinnati.

USEPA (2002), Long Term 1 Enhanced Surface Water Treatment Rule (LT1ESWTR). Federal Register/Vol. 67, No. 9 / Monday, January 14, 2002 / Rules and Regulations, Cincinnati.

Volk C., Bell K., Ibrahim E., Verges D., Amy G., LeChevallier M. (2000), Impact of enhanced and optimized coagulation on removal of organic matter and its biodegradable fraction in drinking water. Wat. Res., 34 (12), 3247-3257. 